\title{
Reconstruction of a historical genealogy by means of STR analysis and Y-haplotyping of ancient DNA
}

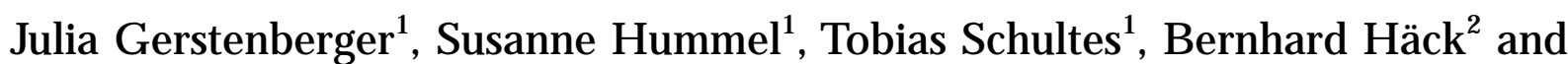 \\ B ernd H errmann ${ }^{1}$
}

${ }^{1} H$ istorische $A$ nthropologie und $H$ umanökologie, Institut für Z oologie und A nthropologie, U niversität $G$ öttingen
${ }^{2} B$ ayerisches $L$ andesamt für $D$ enkmalpflege, $L$ andshut, $G$ ermany

\begin{abstract}
A rchaeological excavations in St M argaretha's church at R eichersdorf, G ermany, in 1993 led to the discovery of eight skeletons, so far assumed to be of the $E$ arls of $K$ önigsfeld, who used the church as a family sepulchre over a period of seven generations from 1546 to 1749. D NA based sex testing and analysis of autosomal short tandem repeat systems (STR ) was carried out to confirm the assumption of kinship. Since five of the individuals were determined as males, analysis of Y-specific STR s seemed feasible. A comparison of $Y$-haplotypes revealed that one individual could not be linked to the $K$ önigsfeld patrilineage, an observation supported by autosomal STR evidence. Two individuals typed as females posed an identification problem, since supposedly only male members of the family were buried in St Margaretha's. $\mathrm{N}$ evertheless, these individuals could tentatively be identified as members of the $\mathrm{H}$ ouse of Königsfeld through genetic fingerprinting.
\end{abstract}

Keywords: aD NA ; Y-haplotyping; ST R -typing; Königsfeld; paternity; kinship

\section{Introduction}

In 1993, during archaeological excavations in St M argaretha's Church at Reichersdorf, Lower Bavaria, Germany, skeletons of eight individuals were recovered. The church was used by the $E$ arls of $K$ önigsfeld as their traditional family burial place from 1546 to 1749 , documented by seven memorial stones in the chancel. A ccording to the inscriptions, eight male members of the House of Königsfeld, spanning altogether seven

Correspondence: Dr Susanne H ummel, H istorische A nthropologie und Humanökologie, Institut für Zoologie und A nthropologie, U niversität Göttingen, B ürgerstraße 50, D-37073 Göttingen, Germany. Tel: 0049551399728 ; Fax: 0049551393642

R eceived 190 ctober 1998; revised 14 January 1999; accepted 15 J anuary 1999 generations, were laid to rest in St M argaretha's. B ased on this information and by evaluating the archaeological finds, seven of the discovered skeletons were identified as the individuals whose names are inscribed on the tombstones. U nfortunately, one skeleton had been destroyed by grave robbers.

Morphological traits (and the fact that remains of female garments were still discernible) gave reason to believe that the individual recovered from grave $\mathrm{Ma} 1$ was a female approximately 30 years old. This observation posed an identification problem, since apparently no proof of a burial of a female in the church existed. It could only be speculated that this individual was affiliated to the $\mathrm{H}$ ouse of $\mathrm{K}$ önigsfeld.

The genealogical positions of the seven identified individuals were known from historical sources ${ }^{1}$ so that the family free in Figure 1 could be reconstructed, 
indicating the relationships between the individuals recovered in St M argaretha's.

G enetic typing by analysis of PCR -amplifiable short tandem repeat (STR) loci is the most promising approach for forensic DNA profiling and has become the method of choice for the identification of human remains $^{2-5}$ and reconstruction of kinship. ${ }^{6-8}$ The comparatively short length of the STR loci (up to $250 \mathrm{bp}$ ) makes them especially suitable for typing ancient D NA (aDNA), characteristically highly degraded. Successful typing of DNA extracted from skeletal material well over a thousand years old is therefore possible. ${ }^{9-11}$ A ccording to archaeological findings, seven of the eight individuals were considered to be male descendants of the House of Königsfeld, connected patrilineally. Therefore we followed a dual strategy in the attempt to determine relationships between the individuals. In addition to analysing autosomal STRS to verify the presumed kinship structures, Y-specific STRs were examined to seek confirmation that all male individuals were representatives of the same patrilineage.

The special properties of the male $\mathrm{Y}$-chromosome make it potentially useful in forensic studies ${ }^{12}$ and paternity testing. ${ }^{13}$ Due to the haploidy of the Y-chromosome, most of it does not recombine during meiosis, so the chromosome is transferred from father to son unchanged, modified only by gradual accumula- tion of mutations. Therefore, the analysis of polymorphisms located in the non-recombining region on the $Y$-chromosome allows retracing of paternal lineages ${ }^{14,15}$ comparable with the analysis of mitochondrial DNA to retrace maternal lineages. ${ }^{16} \mathrm{Y}$-chromosomal STR $s$ are apparently as highly variable and short in length as their autosomal counterparts, ${ }^{17}$ which qualifies them as an investigative tool in the study of aDNA. ${ }^{18}$

\section{Materials and Methods}

\section{Samples}

The skeletal individuals from the graves were identified from archaeological data. The tombstones of the $E$ arls of $K$ önigsfeld were on the walls and not on top of the graves, as might be expected. Thus the contents of the graves could not be directly identified. A rchaeological identification relied on the evaluation of burial objects and on morphological age and sex determination.

The analysis was performed on DNA extracted from bone fragments and isolated teeth. For detailed information on sample material see Table 1.

Contamination Prevention Precautions commonly taken for aDNA work were followed during all stages of sample preparation. ${ }^{19,20}$ To prevent any possible risk of contamination, several precautions were adhered to: separation of preand post-PCR working areas to avoid PCR-product carryover; dedication of equipment to the different laboratory rooms. No-template controls were regularly processed

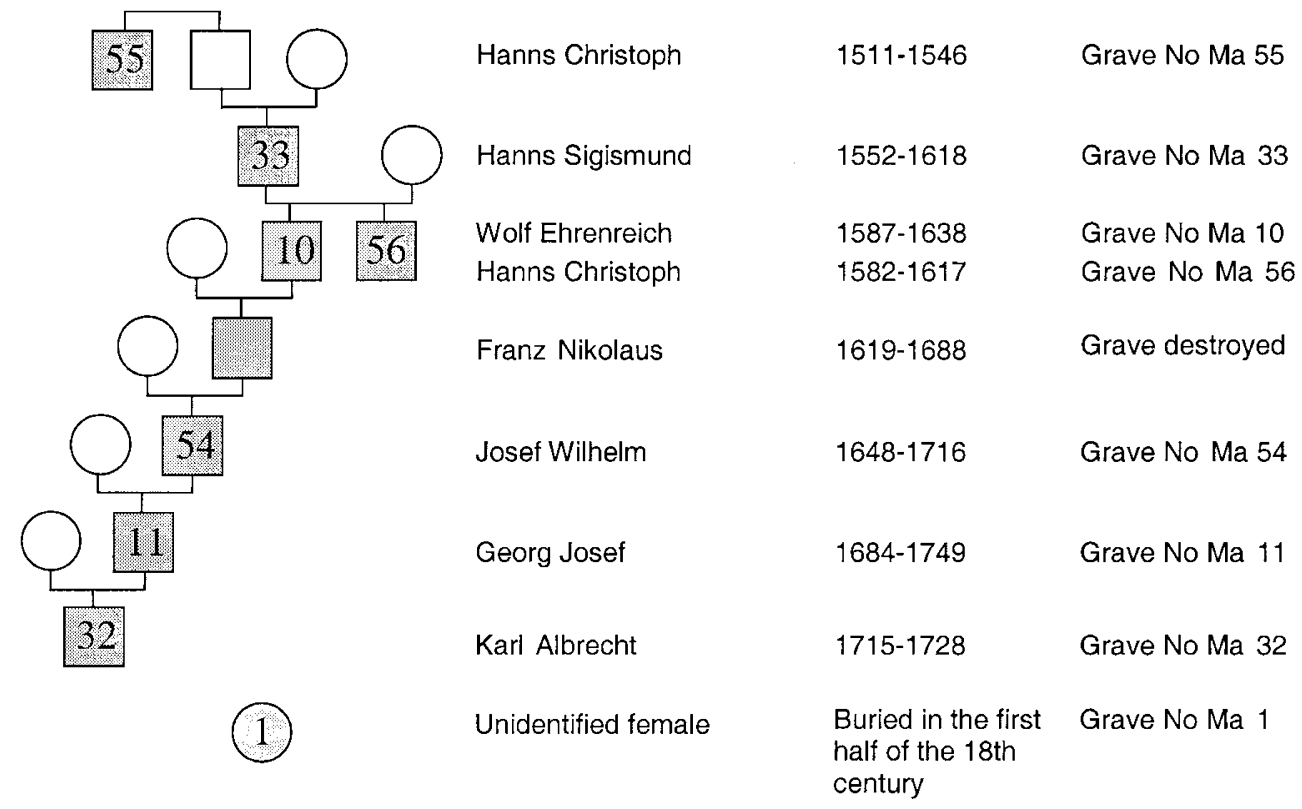

Figure 1 L ineage of the $E$ arls of $K$ önigsfeld. Individuals in the family tree who were buried in St M argaretha's are depicted in grey A grave number was assigned to the skeletal individuals for whom an identification could be achieved. Individual $\mathrm{M}$ a 1 was identified by morphological traits as a 30-year-old female. A $n$ affiliation with the $\mathrm{K}$ önigsfeld individuals was hitherto unknown. A relationship is suggested (see text) 
throughout the DNA extraction to exclude possible contamination of the extraction buffers. Furthermore, no-template controls were used in every PCR run to monitor contamination of reagents.

\section{DNA-Extraction}

For sample preparation, the surfaces of the bone and tooth samples were removed. A fter exposion to UV irradiation $(245 \mathrm{~nm})$ for $20 \mathrm{~min}$, the samples were ground to a fine powder. A liquots of $0.3 \mathrm{~g}$ of bone and tooth powder were suspended in $1.5 \mathrm{ml} 0.5 \mathrm{~m}$ EDTA (pH 8.0) and constantly shaken for $24 \mathrm{~h}$ at room temperature in order to decalcify. A fter centrifugation ( $6000 \mathrm{rpm} / 4 \mathrm{~min}$ ), the supernatants were transferred to an automated nucleic acid extractor $\mathrm{G}$ ene Pure Type 341A (A pplied B iosystems, Weiterstadt, G ermany), which performs a proteinase $\mathrm{K}$ digestion followed by phenol/ chloroform extraction. The DNA was concentrated by binding to silica powder Glassmilk ${ }^{\mathrm{TM}}$, Dianova ( $\mathrm{H}$ amburg, Germany) in the presence of isopropanol and sodium acetate $(2.0 \mathrm{M}, \mathrm{pH} 4.5)$. The Glassmilk ${ }^{\mathrm{T}}-\mathrm{DNA}$ was collected on filtrate membranes, then eluted into $50 \mu \mathrm{l}$ of sterile water A mpuwa ${ }^{\circledR}$, Fresenius (B ad H omburg, Germany).

\section{Sex Determination}

To determine the sex of the individuals, amplification of a sequence of the $X-Y$ homologous gene amelogenin was carried out. $4 \mu \mathrm{l}$ of aDNA extract were amplified in a $50 \mu \mathrm{l}$ reaction mix comprising $50 \mathrm{~mm} \mathrm{KCl}, 10 \mathrm{~mm}$ Tris- $\mathrm{HCl}, 2 \mathrm{~mm}$ $\mathrm{M} \mathrm{gCl}_{2}, 175 \mu \mathrm{M}$ dNTPs, $0.12 \mu \mathrm{m}$ of each primer ${ }^{21}$ and $2 \mathrm{U}$ A mpliTaqG old ${ }^{\mathrm{T} M}$ polymerase. PCR cycling conditions in a DNA Thermal Cycler (PE A pplied Biosystems, Weiterstadt, Germany) were as follows: $60 \mathrm{cycles}$ of $94^{\circ} \mathrm{C} 1 \mathrm{~min}, 50^{\circ} \mathrm{C}$ $1 \mathrm{~min}, 72^{\circ} \mathrm{C} 1 \mathrm{~min}$ with an initial denaturation step of $94^{\circ} \mathrm{C}$ $10 \mathrm{~min}$.

\section{Amplification of the Autosomal STR-loci}

L oci HUMTH $01,{ }^{22}$ HUMCD $4^{23}$ and D $1 S 1656^{24}$ were amplified individually. For loci HU M V WA 31/A, ${ }^{25} \mathrm{HU} M \mathrm{FE} \mathrm{S} / \mathrm{FPS}^{26}$ and HUMF13A $1^{27}$ a triplex PCR approach was employed. $O$ ne primer at each locus was labelled with a fluorescent dye marker. A II PCR s were conducted in a DNA Thermal Cycler (PE A pplied B iosystems). E ach amplification was carried out in a $50 \mu \mathrm{l}$ reaction volume. Due to the lower amplification efficiency of aDNA compared with modern DNA an increased number of PCR cycles is required. Several studies demonstrate that if only a few DNA targets are present a high number of PCR cycles are inevitable. ${ }^{28,29,30}$ If the DNA is

Table 1 Sample materials

\begin{tabular}{|c|c|}
\hline Sample no. & Skeletal element \\
\hline $\begin{array}{l}\text { M a } 1 \\
\text { M a } 10 \\
\text { M } 11 \\
\text { M } ~ \\
\text { M } 32 \\
\text { M } 33 \\
\text { M } 54 \\
\text { M } 55\end{array}$ & $\begin{array}{l}\text { Fibula, tooth } 36 \\
\text { Femur }^{\mathrm{a}} \\
\text { Fibula }^{\mathrm{a}} \\
\text { O s ischium, tooth } 47 \\
\text { Fibula, metatarsal III } \\
\text { R adius, metatarsal V, tooth } 28 \\
\text { U Ina, metatarsal IV } \\
\text { Tooth } 47 \text {, tooth } 44\end{array}$ \\
\hline
\end{tabular}

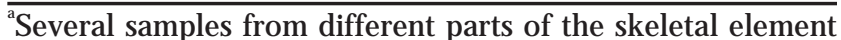
were used for molecular analysis. degraded, amplifications with less than 50 cycles usually show no detectable products. ${ }^{31,9-11}$ Therefore samples were amplified for at least 55 cycles. E very reaction was initiated by $10 \mathrm{~min}$ at $94^{\circ} \mathrm{C}$. R eaction parameters were as follows.

D $1 S 165650 \mathrm{~mm} \mathrm{KCl}, 10 \mathrm{~mm}$ Tris- $\mathrm{HCl}, 2 \mathrm{~mm} \mathrm{M} \mathrm{gCl}, 175 \mu \mathrm{m}$ dNTPs, $0.08 \mu \mathrm{m}$ of each primer, $6 \mu \mathrm{l}$ aDNA extract, $2 \mathrm{U}$ A mpliTaqG old ${ }^{\mathrm{Tm}}$ polymerase; 55 cycles: $94^{\circ} \mathrm{C} 1 \mathrm{~min}, 56^{\circ} \mathrm{C}$ $1 \mathrm{~min}, 72^{\circ} \mathrm{C} 1 \mathrm{~min}$;

TH 01: $50 \mathrm{~mm} \mathrm{KCl}, 10 \mathrm{~mm}$ Tris- $\mathrm{HCl}, 2 \mathrm{~mm} \mathrm{M} \mathrm{gCl}, 175 \mu \mathrm{m}$ dNTPs, $0.14 \mu \mathrm{m}$ of each primer, $4 \mu \mathrm{l}$ aDNA extract, $2.5 \mathrm{U}$ A mpliTaqG old ${ }^{\mathrm{Tm}}$ polymerase; 55 cycles: $94^{\circ} \mathrm{C} 1 \mathrm{~min}, 50^{\circ} \mathrm{C}$ $1 \mathrm{~min}, 72^{\circ} \mathrm{C} 1 \mathrm{~min}$;

CD 4: $50 \mathrm{~mm} \mathrm{KCl}, 10 \mathrm{~mm}$ Tris- $\mathrm{HCl}, 2 \mathrm{~mm} \mathrm{M} \mathrm{gCl}, 175 \mu \mathrm{m}$ dNTPs, $0.12 \mu \mathrm{m}$ of each primer, $5 \mu \mathrm{l}$ aD NA extract, $2.5 \mathrm{U}$ A mpliTaqG old ${ }^{\mathrm{TM}}$ polymerase; 55 cycles: $94^{\circ} \mathrm{C} 1 \mathrm{~min}, 53^{\circ} \mathrm{C}$ $1 \mathrm{~min}, 72^{\circ} \mathrm{C} 1 \mathrm{~min}$;

Triplex PCR VWA/FE S/F 13A 1: $50 \mathrm{~mm} \mathrm{KCl,} 10 \mathrm{~mm}$ Tris$\mathrm{HCl}, 2.0 \mathrm{~mm} \mathrm{M} \mathrm{gCl}, 175$ um dNTPs, 0.1 um for each primer of $F E S$ and $F 13 A 1$ and $0.04 \mu \mathrm{m}$ of each primer of VWA, $5 \mu \mathrm{l}$ aDNA extract, $2 \mathrm{U}$ A mpliTaqG old ${ }^{\mathrm{Tm}}$ polymerase; 60 cycles: $94^{\circ} \mathrm{C} 1 \mathrm{~min}, 50^{\circ} \mathrm{C} 1 \mathrm{~min}, 72^{\circ} \mathrm{C} 1 \mathrm{~min}$.

Amplification of the Y-chromosomal STR-loci The Y-specific STR -loci DY S19, DY S390, DY S389I/II ${ }^{32,33}$ were amplified in a quadruplex-PCR. U sage of the primer pair DY S389 as described by Kayser et $\mathrm{al}^{32}$ and de $\mathrm{K}$ nijff et $\mathrm{al}^{33}$ results in the amplification of two products of different sizes. A llele lengths of system DY S389l are in the range 239-263 bp, the length range of alleles of the larger system DY S389II is 353-385 bp. To accommodate the primer pair to the usage on $\mathrm{aDNA}$, the reverse primer was modified so that the generated products were $94 \mathrm{bp}$ shorter. ${ }^{18}$ The loci were coamplified in a $50 \mu \mathrm{l}$ reaction volume containing $50 \mathrm{~mm} \mathrm{KCl}, 10 \mathrm{~mm}$ Tris- $\mathrm{HCl}$ $2.0 \mathrm{~mm} \mathrm{MgCl} 2,175 \mu \mathrm{m}$ dNTPs, $0.1 \mu \mathrm{m}$ of each primer of DY S19, DYS390 and DYS389, $6 u$ l aDNA extract, $2.5 \mathrm{U}$ A mpliTaqG old ${ }^{\mathrm{Tm}}$ polymerase. $\mathrm{PCR}$ cycling conditions were as follows: $55 \mathrm{cycles}$ of $94^{\circ} \mathrm{C} 1 \mathrm{~min}, 51^{\circ} \mathrm{C} 1 \mathrm{~min}, 72^{\circ} \mathrm{C} 1 \mathrm{~min}$

\section{Fragment Length Determination}

A nalysis of the amplified fragments was carried out by using an automated fluorescence fragment length detection system GeneScan 672 (A pplied Biosystems, Weiterstadt, Germany) on an A BI Prism 373A stretch D NA Sequencer (PE A pplied Biosystems, Weiterstadt, G ermany). Electrophoresis was carried out in denaturing $6 \%$ polyacrylamide gels. L ength of the DNA fragments was determined from the internal lane standard GeneScan 350-ROX (Perkin Elmer, Weiterstadt, Germany).

\section{Results}

\section{Chromosomal DNA Analysis}

Sex Testing The sex of the individuals was determined by amplification of $Y$-specific loci and a segment of the amelogenin gene which exhibits a length dimorphism, resulting in $X$-specific fragments of $106 \mathrm{bp}$ and $Y$-specific products $112 \mathrm{bp}$ long. 
Reproducible results of the amplifications of $Y$-specific STR loci clearly identified five individuals as male. A II samples, except for Ma56, yielded products after amelogenin amplification (Table 2).

R epeated amplifications (five times) of the amelogenin sequence from samples of $M$ a 32 generated the $X$-specific product. Since all amplifications were successful, a general good quality of the DNA can be assumed, so that drop-out of the $Y$-specific fragment due to DNA degradation ${ }^{20}$ is unlikely. Consequently, this individual was typed as female, a result which challenges the archaeological identification of $\mathrm{M}$ a 32 as $\mathrm{K}$ arl A Ibrecht.

In the case of individual Ma33, an inconsistency arises between the results of the amplification of the amelogenin sequence and the $Y$-specific loci. A Ithough the male status of this individual was clearly manifested by determination of a Y-haplotype, amelogenin amplifications yielded only $X$-specific fragments. It can be assumed that drop-out of the $Y$-specific fragment has occurred here. Samples from the left fibula of Ma 33 used for amelogenin amplification showed products in only $50 \%$ of the amplifications, indicating a high degree of DNA degradation for this skeletal element. For $Y$-haplotyping, samples derived from a metatarsal of the same individual showed reproducible results. The discrepancy between the results of $Y$-haplotyping and amelogenin amplification can thus be explained by the usage of two DNA extracts, with differing suitability for molecular genetic analysis. ${ }^{34}$

Short Tandem Repeats A mplifications of six STR loci showed amplification products for all skeletal samples, with the exception of $\mathrm{M}$ a 56 . Figure 2 shows an electrophoretogram displaying PCR products of a multiplex amplification of a sample.
DNA extracted from historical bone material exhibits several characteristical features, namely the limited number of targets and an increased degree of DNA degradation. L ow concentrations of templates may lead to allelic or complete locus drop-out, due to stochastic differences in allele copy number. ${ }^{35} \mathrm{~A}$ II samples were therefore analysed at least five times to avoid falsehomozygote typing. ${ }^{36}$ A nother characteristic of STR amplifications lies in the generation of stutter bands. These extra bands are caused by enzyme slippage during PCR. ${ }^{37,38}$ In general, the artefactual bands can be easily identified, since they exhibit a weaker product signal. With highly degraded aDNA, however, the amount of stutter products may exceed the quantity of the correct product ${ }^{39,34}$ impeding determination of the samples' allelic composition. However, since only the true alleles will be reproduced, the authentic genotype of the sample should be determinable after repeated amplifications. Nevertheless, for some of the individuals, a distinct identification of allele peaks was not possible for every locus. In cases where an unequivocal determination could not be made, more than two alleles are listed in Table 3, representing the STR genotypes of the K önigsfeld individuals.

\section{Y-chromosomal STR Systems -}

$Y$-haplotypes In a quadruplex-PCR, the tetrameric Y-STR systems were amplified from five of the skeletons. A four-locus Y-haplotype could be set up for all individuals (Table4). Four individuals exhibit the same Y-haplotype, indicating that they belong to the same patrilineage, presumably the lineage of descendants of the $\mathrm{H}$ ouse of $\mathrm{K}$ önigsfeld. H owever, a different haplotype of individual Ma11 renders its affiliation to the K önigsfelder paternal lineage impossible.

Table 2 Sex determination of the eight skeletons

\begin{tabular}{lcccc}
\hline Skeleton & $\begin{array}{c}\text { Y-specific STR } \\
\text { results }\end{array}$ & A melogenin & $\begin{array}{c}\text { Sex determined by } \\
\text { molecular examination }\end{array}$ & $\begin{array}{c}\text { Sex expected from } \\
\text { archaeological findings }\end{array}$ \\
\hline Ma 1 & - & X & Female & Female \\
Ma 10 & Yes & XY & M ale & Male \\
Ma 11 & Yes & XY & M ale & Male \\
Ma 32 & - & $X$ & Female & Male \\
Ma 33 & Yes & X ale & Male \\
Ma 54 & Yes & XY & M ale & Male \\
Ma 55 & Yes & XY & M ale & Male \\
Ma 56 & - & - & - &
\end{tabular}




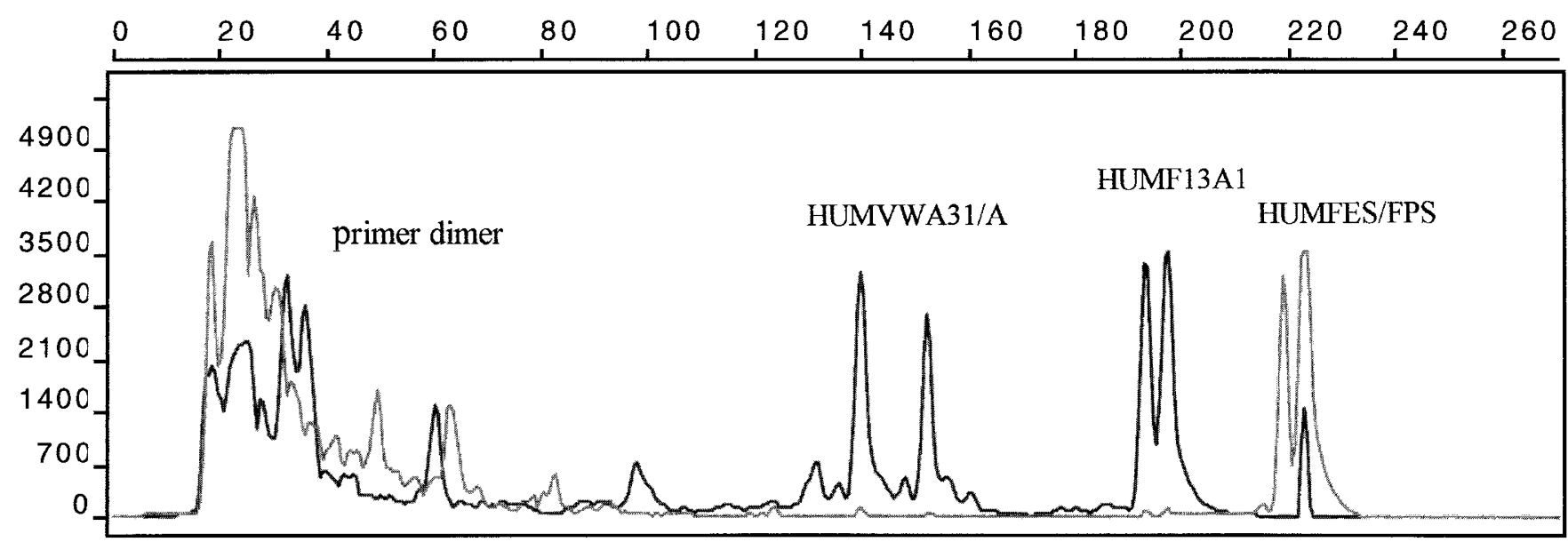

Figure 2 E lectrophoretogram displaying PCR products of a triplex amplification of a tooth sample from individual Ma 32 . Peaks represent fluorescent intensities of dye-labelled DNA products. The size of the products, in bases, is shown along the $x$ axis. For locus HUMVWA 31/A, alleles 14/17 were determined; for HUMF13A 1, the alleles6/7 were amplified. For HUM FES/FPS, the allelic designation was 10/11. Small stutter peaks one repeat unit shorter than the true allele products can be made out in system H U M V WA 31/A. A pull-up signal can be distinguished in the second allele peak of system HUM FES/FPS. The peaks on the left up to $80 \mathrm{bp}$ long, so called primer dimer, are the result of non-specific primer-primer interactions

Table 3 STR genotypes of the eight skeletons

\begin{tabular}{lcccccc}
\hline Individual & $\begin{array}{c}\text { HUM VWA 31/A } \\
\text { 135bp-167bp }\end{array}$ & $\begin{array}{c}\text { HUM F 13A 1 } \\
\text { 181bp-235bp }\end{array}$ & $\begin{array}{c}\text { HUM FE S/FPS } \\
\text { 213bp-237bp }\end{array}$ & $\begin{array}{c}\text { HUMCD 4 } \\
86 b p-121 b p\end{array}$ & $\begin{array}{c}\text { HUM TH 01 } \\
\text { 154bp-178bp }\end{array}$ & $\begin{array}{c}\text { D 1S1656 } \\
122 b p-160 b p\end{array}$ \\
\hline Ma 1 & $14 / 17$ & $6 / 7$ & $10 / 11$ & $10 / 11$ & $6 / 8$ & $15.3 / 19.3$ \\
Ma 10 & $16 / 18$ & $5 / 7$ & $(10 / 11 / 12)$ & $5 / 11$ & $6 /(8)$ & $12 /(18.3 / 19.3)$ \\
Ma 11 & $14 / 17$ & $6 / 7$ & $10 /(11)$ & $5 / 12$ & $-/-$ & $11 /(18.3 / 19.3)$ \\
Ma 32 & $14 / 17$ & $6 / 7$ & $10 /(11)$ & $5 / 11$ & $(9) /-$ & $(17.3 / 18.3 / 19.3)$ \\
Ma 33 & $15 / 17$ & $5 /(5)$ & $10 / 11$ & $6 / 10$ & $9 /(9)$ & $-/-$ \\
Ma 54 & $14 / 17$ & $5 / 7$ & $10 / 11$ & $6 / 11$ & $-/-$ & $(18.3) / 19.3$ \\
Ma 55 & $16 / 17$ & $5 / 5$ & $10 / 10$ & $(5 / 6 / 8)$ & $6 / 9.3$ & $-/-$ \\
Ma 56 & $14 /-$ & $-/-$ & $-/-$ & $-/-$ & $-/-$ & $-/-$
\end{tabular}

${ }^{a}$ A llele designation for all loci is based on the number of repeat units. ${ }^{45}$ Fragment lengths were determined after electrophoresis in PAA gels. To be typed unequivocally as homozygous for a given locus, at least five amplifications must show consistent reproduction of the same allele, otherwise the second allele is in parentheses. A llele products which could not be detected in at least three amplifications are also in parentheses. In some cases, determination was not possible: this is signified by a dash.

Table 4 Y-haplotypes of five Königsfeld individuals ${ }^{\mathrm{a}}$

\begin{tabular}{lcccc}
\hline Individual & $\begin{array}{c}\text { DYS19 } \\
\text { 174bp-210bp }\end{array}$ & $\begin{array}{c}\text { DYS390 } \\
\text { 191bp-227bp }\end{array}$ & $\begin{array}{c}\text { DYS389| } \\
145 \mathrm{bp}-169 \mathrm{bp}\end{array}$ & $\begin{array}{c}\text { DYS389|I } \\
259 \mathrm{bp}-291 \mathrm{bp}\end{array}$ \\
\hline Ma 10 & 14 & 23 & 12 & 28 \\
Ma 11 & 14 & $(24)$ & 13 & 33 \\
Ma 33 & 14 & 23 & 12 & 28 \\
Ma 54 & 14 & 23 & 12 & $(28)$ \\
Ma 55 & 14 & 23 & 12 & (28) \\
\hline
\end{tabular}

${ }^{a}$ We were provided with only a very limited amount of skeletal material. R esults for the $Y$-specific STR systems were repeated by quadruplex PCR until at least two verifying results per STR system were obtained. R esults in parentheses indicate that only a single result could be produced, due to the scarcity of material. 


\section{Evaluation of the Genetic Evidence}

In Figure 3, results of autosomal and Y-specific STR genotyping are presented in combination with the family tree. The following deductions can be made.

Individual 33 cannot be considered the biological father of individual 10. Three apparent exclusions of paternity were obtained.

The skeletal remains of the presumed father of $\mathrm{M}$ a 54 were not available for typing, since the grave was destroyed prior to the archaeological excavations. In such a case, typing of a male relative in the paternal line will offer an indirect proof of paternity. ${ }^{15}$ Since individual M a 54 and his alleged grandfather $M$ a 10 exhibit the same Y-haplotype, affiliation of M a 54 with the K önigsfeld patrilineage can be assumed.

Individual 54 is excluded from paternity of individual 11, based on an exclusion in system HU M CD 4 and by the results of $Y$-STR typing.

Due to autosomal evidence, individual 11 can be included as putative father of individual 32. A formula for computation of the probability of paternity (W $)^{40}$ in cases lacking a mother is described elsewhere. ${ }^{41} \mathrm{~A}$ llele frequencies were derived from data gathered in recent

\begin{tabular}{|c|c|c|c|c|c|}
\hline VWA & F13A1 & FES & CD4 & TH01 & D1S1656 \\
\hline $16 / 17$ & $5 / 5$ & $10 / 10$ & $(5 / 6 / 8)$ & $6 / 9.3$ & -- \\
\hline $15 / 17$ & $5 /(5)$ & $10 / 11$ & $6 / 10$ & $9 /(9)$ & -- \\
\hline $16 / 18$ & $5 / 7$ & $(10 / 11 / 12)$ & $5 / 11$ & $6 /(8)$ & $12(18.3 / 19.3)$ \\
\hline $14 / 17$ & $5 / 7$ & $10 / 11$ & $6 / 11$ & -- & $(18.3) / 19.3$ \\
\hline $14 / 17$ & $6 / 7$ & $10 /(11)$ & $5 / 12$ & -- & $11 /(18.3 / 19.3)$ \\
\hline $14 / 17$ & $6 / 7$ & $10 /(11)$ & $5 / 11$ & $(9) /-$ & $(17.3 / 18.3 / 19.3)$ \\
\hline $14 / 17$ & $6 / 7$ & $10 / 11$ & $10 / 11$ & $6 / 8$ & $15.3 / 19.3$ \\
\hline
\end{tabular}

G erman populations. ${ }^{42}$ For the putative father-son pair, a probability of paternity of $\mathrm{W}=85 \%$ was computed.

It is interesting to note that individual 33 and individual 10 exhibit an identical Y-haplotype; nevertheless a definite exclusion of paternity for $\mathrm{M}$ a 33 can be obtained from the autosomal STR evidence. $Y$ et it can be observed that Ma55 exhibits the same Y-haplotype as Ma10 and reveals an autosomal STR genotype that would not be in contradiction with paternity of $M a 55$ to $M a 10$. These results led to the suggestion that the skeletons of $M$ a 55 and $M$ a 33 had been mistaken for each other. This seems plausible considering that the tombstones were not directly affiliated with the graves, but were attached to the walls of the chancel. A probability of paternity of $\mathrm{W}=79 \%$ can be derived for the putative father-son pair Ma55 and $\mathrm{Ma} 10$.

\section{Identification of Individual Ma 1}

A rchaeological data could not identify individual Ma 1 although historical sources ${ }^{1}$ do present evidence of the burial of a female in St M argaretha's.

$$
\begin{array}{cc}
\begin{array}{c}
\text { Suggested family tree } \\
\text { of the skeletal }
\end{array} & \text { Y-haplotypes } \\
\text { individuals according } & \text { determined in this } \\
\text { to historical sources } & \text { study }
\end{array}
$$
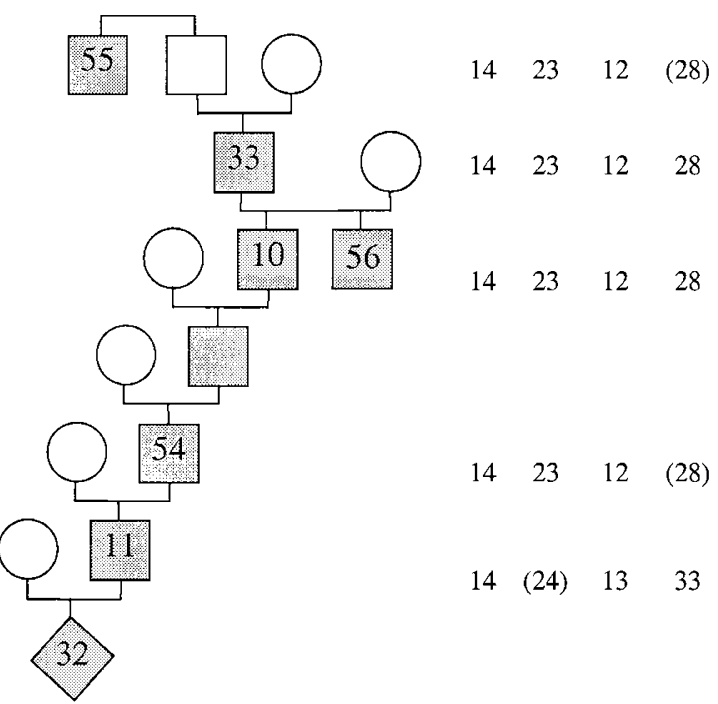

$14 \quad(24) \quad 13 \quad 33$

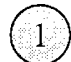

Figure 3 Presentation of the STR genotypes and Y-haplotypes in combination with the family tree, which was reconstructed according to archaeological and historical findings. For individual $\mathrm{M}$ a 56, a determination of the genotype was not possible, due to the severe degree of DNA degradation in the skeletal material 
A rchaeological and morphological findings determined individual $\mathrm{Ma} 1$ as an approximately 30 -year-old female buried at the beginning of the 18th century. Therefore it is possible to fit $M$ a 1 into the family tree as putative mother of individual Ma32. The observed genotypes of the three individuals (Ma1, Mall and Ma 32) exhibit a pattern which would be expected in a family group (Table 5). For this trio, a probability of $W=85 \%$ for $M a 11$ and $W=98 \%$ for $M a 1$ can be obtained.

We interpreted the results to the effect that $M a 1$ is $M$ aria A nna von Königsfeld, wife of Georg Josef von $K$ önigsfeld (Ma11). A ccording to historical sources, ${ }^{1}$ $M$ aria A nna was born in 1686. A fter marriage to $G$ eorg Josef for nine years, she died in 1722 .

For M a 32 female sex was clearly determined, thus excluding the identification of this individual as $\mathrm{Karl}$ A lbrecht. Further studies of historical sources revealed that four of his sisters were buried in St M argaretha's. A II of them died as infants and were possibly laid to rest in the same grave as their brother. So it is not unlikely that $\mathrm{Ma} 32$ is indeed one of the sisters of $\mathrm{K}$ arl A lbrecht.

\section{Discussion and Conclusion}

$U p$ to now the reconstruction of kinship in (pre) historic family groups or societies has relied upon the comparison of phenotypic traits. ${ }^{43}$ Thus the results have been of a more or less tentative nature. The case of the $\mathrm{K}$ önigsfeld individuals presented an ideal opportunity of showing that kinship structures in skeletal remains can most feasibly be validated by examining the genetic variation between individuals. DNA typing led to the establishment of the paternal lineage of the descendants of the H ouse of $K$ önigsfeld. It could be deduced from the results of $Y$-haplotyping that one individual buried in the Königsfeld sepulchre cannot be considered consanguine with the other male individuals. We can only speculate that this individual is the product of adultery or that the identification of $\mathrm{Ma} 11$ as a member of the House of Königsfeld is simply incorrect.

However, the following can be concluded from the STR analysis. It is very probable that $\mathrm{Ma} 11, \mathrm{Ma} 1$ and Ma 32 present a family trio. In accordance with archaeological experience and historical knowledge, we believe it is rather unlikely that a family not belonging to the Königsfeld genealogy was laid to rest in the sepulchre.

For Ma32, a morphological sex-determination was not possible. $\mathrm{N}$ evertheless, the age of the individual was determined as 15 years old at most (Schröter $P$, personal communication). Presumably due to this, archaeologists identified $\mathrm{M}$ a 32 as $\mathrm{K}$ arl A lbrecht von K önigsfeld, who died at age 13. However, molecular typing of M a 32 as female challenges this assumption. It might be speculated that the $\mathrm{Y}$-encoded amelogenin gene is deleted in this individual. A frequency of $0.6 \%$ is reported for this deletion polymorphism in population samples from around the world. ${ }^{44} \mathrm{~A}$ Ithough the frequency in past populations is unknown, it seems rather unlikely that a deletion of this kind should have occurred in this individual. Since the DNA derived from samples of $\mathrm{M}$ a 32 proved to be well preserved, it is also rather unlikely that a drop-out of the $Y$-specific fragment has occurred in the amelogenin amplifications. Therefore, it can be assumed that $\mathrm{M}$ a 32 is indeed a sister of $\mathrm{K}$ arl $\mathrm{A}$ lbrecht.

It would have been interesting to compare $\mathrm{Y}$-haplotypes of living paternal relatives with the results obtained from the historical specimens. A las, the last paternal descendant of the $\mathrm{K}$ önigsfelder lineage died in 1815. ${ }^{1}$

Corroboration of archaeological, morphological and molecular evidence led to the tentative identification of $\mathrm{Ma} 1$ as $\mathrm{M}$ aria A nna of Königsfeld. In this and other cases where inclusive statements concerning relationships are made, it cannot be emphasised too strongly that the calculated probabilities of paternity and maternity represent hypothetical values because data

Table 5 STR genotypes of the putative family trio $M$ a 1 (mother), M a 11 (father), M a 32 (child)

\begin{tabular}{lcccccc}
\hline Skeleton & HUM VWA 31/A & HUMF13A 1 & HUMFES/FPS & HUMCD 4 & HUM TH 01 & D 1S1656 \\
\hline Ma 1 & $14 / 17$ & $6 / 7$ & $10 / 11$ & $10 / 11$ & $6 / 8$ & $15.3 / 19.3$ \\
Ma 11 & $14 / 17$ & $6 / 7$ & $10 /(11)$ & $5 / 12$ & $-/-$ & $11 /(18.3 / 19.3)$ \\
Ma 32 & $14 / 17$ & $6 / 7$ & $10 /(11)$ & $5 / 11$ & $(9) /-$ & $(17.3 / 18.3 / 19.3)$ \\
\hline
\end{tabular}


on historical allelic frequencies is not available. M oreover, the individuals examined were members of a fairly small aristocratic class. M arriages among closely related individuals were presumably rather common. This might result in allelic frequencies deviating from frequencies in recent populations assumed to be in $\mathrm{H}$ ardy-Weinberg equilibrium.

H owever, despite these objections and characteristic features of aDNA mentioned above, it can be shown that the molecular approach is the most powerful tool for the identification and reconstruction of kinship of skeletal human remains.

\section{Acknowledgements}

We are indebted to $\mathrm{Dr}$ Peter Schröter, A nthropologische Staatssammlung $M$ ünchen, for providing the data on morphological sex and age determination. 0 ur thanks are also due to Professor Dr Gisela Grupe, A nthropologische Staatssammlung $M$ ünchen, for arranging access to the sample material.

\section{References}

1 Hobmaier M: Die Grafen v. Königsfeld auf Niederaichbach. Verhandlungen des historischen Vereins für $\mathrm{N}$ iederbayern 1889; 26: 163-326.

2 Clayton TM, Whitaker JP, M agiure $\mathrm{CN}$ : Identification of bodies from the scene of a mass disaster using DNA amplification of short tandem repeat (STR) loci. Forens Sci Int 1995; 76: 7-15.

3 Sparkes $\mathrm{R}$ et al: The validation of a 7-locus multiplex STR test for use in forensic casework. (II) A rtefacts, casework studies and success rates. Int J L egal Med 1996; 109: 195-204.

4 Lygo JE et al: The validation of short tandem repeat (STR ) loci for use in forensic casework. Int J L egal M ed 1994; 107: 77-89.

5 J effreys A J, A llen MJ, H agelberg E, Sonnberg A : I dentification of the skeletal remains of J osef M engele by DNA analysis. Forens Sci Int 1992; 56: 65-76.

6 A lford R L, H ammond H A, Coto I, Caskey CT: R apid and efficient resolution of parentage by amplification of short tandem repeats. Hum G enet 1994; 55: 190-195.

$7 \mathrm{G}$ ill $\mathrm{P}$ et al: Identification of the remains of the R omanow family by DNA analysis. Nat G enet 1994; 6: 130-135.

8 Gunn PR, Truemann K, Stapleton P, Klarkowski D B: DNA analysis in disputed parentage: The occurrence of two apparently false exclusions of paternity, both at short tandem repeat (STR) loci, in the one child. Electrophoresis 1997; 18: 1650-1652.

9 Hummel S, Herrmann B: Y-chromosome-specific DNA amplified in ancient human bone. Naturwissenschaften 1991; 78: 266-267.
10 Zierdt $\mathrm{H}, \mathrm{H}$ ummel S, Herrmann B: A mplification of human short tandem repeats from medieval teeth and bone samples. H um Biol 1996; 68: 185- 199.

11 Schultes T, H ummel S, Herrmann B : Z uordnung isolierter Skelettelemente mittels aD NA -typing. A nthrop A nz 1997; 55: 207-216.

12 Corach D et al: A dditional approaches to D NA typing of skeletal remains: The search for 'missing' persons killed during the last dictatorship in A rgentina. Electrophoresis 1997; 18: 1608-1612.

13 Pena SD J, Chakraborty R: Paternity testing in the DNA era. Trends $G$ enet 1994; 10: 204-209.

14 Foster EA, Jobling MA, Taylor PG et al: Jefferson fathered slave's last child. N ature 1998; 396: 27-28.

15 Santos FR, Epplen JT, Pena SDJ: Testing deficiency paternity cases with a $Y$-linked tetranucleotide repeat polymorphism. In: Pena SD J, Chakraborty R, E pplen J T, Jeffreys $A$ (eds). DNA fingerprinting: The state of the sciences. Birkhäuser: B asel, 1993, pp 221-230.

16 Jehaes $E$ et al: $M$ itochondrial DNA analysis on remains of a putative son of Louis XVI, K ing of France and MarieA ntoinette. Eur J H um Genet 1998; 6: 383-395.

17 R oewer L, A rnemann J, Spurr NK, G rzeschik K H, E pplen $\mathrm{JT}$ : Simple repeat sequences on the human $Y$ chromosomes are equally polymorphic as their autosomal counterparts. H um G enet 1992; 89: 389-394.

18 Schultes T, Hummel S, Herrmann B: A mplification of $Y$-chromosomal STRs from ancient skeletal material. H um G enet 1999 (in press).

19 Schmidt T, H ummel S, Herrmann B: Evidence of contamination in PCR laboratory disposables. Naturwissenschaften 1995; 82: 423-431.

20 Lassen C, Hummel S, Herrmann B: PCR based sex identification in ancient human bones by amplification of $X$ - and $Y$ chromosomal sequences. A comparison. A ncient Biomol 1996; 1: 25-33.

21 M annucci A, Sullivan KM, Ivanov PL, Gill P: Forensic application of a rapid and quantitative DNA sex test by amplification of the $X-Y$ homologous gene amelogenin Int J Legal Med 1994; 106: 190-193.

22 Polymeropoulos $\mathrm{MH}, \mathrm{X}$ iao $\mathrm{H}, \mathrm{R}$ ath $\mathrm{S}, \mathrm{M}$ erril $\mathrm{CR}$ : Tetranucleotide repeat polymorphism at the human tyrosine hydroxylase gene (TH). Nucleic Acids Res 1991; 19 3753.

23 Casarino $L$ et al: Forensic evaluation of HUMCD 4: A n I talian database. Int J L egal M ed 1996; 109: 49-51.

$24 \mathrm{~L}$ areu MV, Barral S, Salas A, Pestoni C: Sequence variation of a hypervariable short tandem repeat at the D $1 S 1656$ locus. Int J L egal M ed 1998; 111: 244-247.

25 Kimpton C, Walton A, Gill P: A further tetranucleotide repeat polymorphism in the vWF gene. $\mathrm{H}$ um $\mathrm{M}$ ol $\mathrm{G}$ enet 1992; 1: 287.

26 Polymeropoulos $\mathrm{MH}, \mathrm{X}$ iao $\mathrm{H}, \mathrm{R}$ ath $\mathrm{S}$, Merril CR: Tetranucleotide repeat polymorphism at the human c-fes/ fps proto-oncogene. N ucleic A cids Res 1991; 19: 4018.

27 Polymeropoulos $\mathrm{MH}, \mathrm{R}$ ath $\mathrm{DS}, \mathrm{X}$ iao $\mathrm{H}$, M erril CR Tetranucleotide repeat polymorphism at the human coagulation factor X III A subunit gene (F 13A ). N ucleic A cids Res 1991; 19: 4036

28 K rings $M$, Stone A, Schmitz RW, K rainitzki H, Stoneking $M, P$ ääbo S: N eandertal DNA sequences and the origin of modern humans. Cell 1997; 90: 19-30. 
29 G enest DR, Choi-H ong SR, Tate JE, Q ureshi F, Jacques SM, Crum C: Diagnosis of congenital syphilis from placental examination: Comparison of histopathology, Steiner stain, and polymerase chain reaction for Treponema pallidum DNA. H um Pathol 1996; 27: 365-372.

30 Faerman $M$, Jankauskas $R$, Gorski A, Bercovier $H$, Greenblatt $C L$ : Prevalence of human tuberculosis in a medieval population of $L$ ithuania studied by ancient D NA analysis. A ncient Biomol 1997; 1: 205-214.

31 R ameckers J, H ummel S, H errmann B: H ow many cycles does a PCR need? Determinations of cycle numbers depending on the number of targets and the reaction efficiency factor. Naturwissenschaften 1997; 84: 259-262.

$32 \mathrm{~K}$ ayser $\mathrm{M}$ et al: Evaluation of $\mathrm{Y}$-chromosomal STR s: a multicenter study. Int J L egal Med 1997; 110: 125-133.

33 de $\mathrm{K}$ nijff $\mathrm{P}$ et al: Chromosome $Y$ microsatellites: population genetic and evolutionary aspects. Int J L egal M ed 1997; 110: 134-140.

34 Schultes T, Hummel S, Herrmann B: Recognizing and overcoming inconsistencies in microsatellite typing of ancient DNA samples. A ncient Biomol 1997; 1: 227-233.

$35 \mathrm{~K}$ impton $\mathrm{C}$ et al: Evaluation of an automated DNA profiling system employing multiplex amplification of four tetrameric STR loci. Int J L egal M ed 1994; 106: 302-311.

36 Schmerer WM, Hummel S, Herrmann B: Reproduzierbarkeit von aDNA typing. Anthrop Anz 1997; 55: 199-206.
$37 \mathrm{H}$ ite J M , E ckert K A , Cheng K C: Factors affecting fidelity of DNA synthesis during PCR amplification of $d(C-A) n$ $\cdot d(G-T) n$ microsatellite repeats. Nucleic A cids Res 1996; 24: 2429-2434.

38 Clayton TM, Whitaker J P, Sparkes R, G ill P: A nalysis and interpretation of mixed forensic stains using DNA STR profiling. Forens Sci 1998; 91: 55-70.

39 O delberg SI, White $R: A$ method of accurate amplification of polymorphic CA -repeat sequences. PCR M ethods A ppl 1993; 3: 7-12.

40 Essen-Möller E: Die Beweiskraft der Ähnlichkeit im Vaterschaftsnachweis-theoretische Grundlagen. $M$ itt Anthrop Ges (Wien) 1938; 68: 9-53.

41 B renner $\mathrm{CH}$ : A note on paternity computation in cases lacking a mother. Transfusion 1993; 33: 51-54.

42 H uckenbeck W, Kuntze K, Scheil H G : The D istribution of the Human DNA-PCR Polymorphisms Köster: Berlin, 1997.

43 A It K W, Pichler S, Vach W, K líma B, V Icek E, Sedlmeier J: Twenty-five thousand-year-old triple burial from Doln Vestonice: A n ice-age family? A m J P hys A nthropol 1997 102: 123-131.

44 Santos FR, Pandya A, Tyler-Smith C: R eliability of D NA based sex tests. $N$ at $\mathrm{G}$ enet 1998; 18: 103-104.

45 DNA Commission of the ISFH: Report concerning further recommendations of the DNA Commission of the ISFH regarding PCR -based polymorphisms in STR (short tandem repeats). Int J Legal Med 1994; 107: 159-160. 